\title{
Authors
}

Ala' Omar Dandis, Mohammad Badea Al Haj Eid, Robin Robin, Nathalie Wierdak

\begin{abstract}
Purpose - The main objective of this paper is to investigate the factors affecting customer lifetime value (CLV) for internet service providers in Jordan, namely technical quality, functional quality, brand credibility, confidence benefits, special treatment benefits, customer satisfaction and commitment.

Design/methodology/approach - An online survey was conducted involving a sample of 481 respondents. SPSS was used to analyse the data and test the proposed relationships, while SmartPLS was used to examine the robustness of our results.

Findings - Results showed that confidence benefits, special treatment benefits and brand credibility had a significant and positive impact on customer satisfaction and commitment, with brand credibility appearing as the most influential factor leading to customer satisfaction and commitment, and ultimately customer lifetime value (CLV). Furthermore, research reveals an insignificant relationship between functional quality, technical quality and customer satisfaction.

Practical Implications: Services providers seeking to increase CVL need to build strong and sustainable relationships with their customers.

Originality/value: This study incorporates a set of crucial customer relationship management (CRM) strategies that could be universally applied to enhance customers benefits and business performance. This is also the first study of its kind conducted in the Middle East, particularly in Jordan.
\end{abstract}

Keywords: Customer lifetime value, Service quality, brand credibility, confidence benefits, special treatment benefits, customer satisfaction, commitment. 


\section{An Empirical Investigation of the Factors Affecting Customer Lifetime Value}

\section{Introduction}

Customer lifetime value (CLV) is an essential component of customer relationship management (CRM), and it is one of the main criteria used to assess marketing decisions making (AboElHamd et al., 2021; Dahana, Miwa, \& Morisada, 2019; Qi et al., 2012). It is considered an essential indicator of evaluating customer relationship performance, demonstrating that businesses should focus on developing and maintaining profitable long-term relationships with the customers rather than detached transactions (Chen, 2012). Despite the increasing attention that CRM is gaining across academics and practitioners (Buttle, 2019; Chen, 2012), its overall concept remains divergent. Its linkages with customer benefits and the firm's performance have not been explicitly connected (Chen, 2012). There has also been a call for research in investigating CLV as one of the core dimensions in understanding customer behaviours in the internet service market (Akroush and Mahadin, 2019) as studies focusing on testing the antecedents of CLV within a CRM framework in the internet service providers are limited. Wang et al. (2016) also suggested that future research should examine how the element of quality and brand credibility can improve CLV. In other words, customer lifetime value (CLV) is especially vital for service providers whose offerings are mostly intangible, and experience or credence based (Wirtz and Lovelock, 2018). This motivates researchers to compete in developing models to maximize the value of CLV (AboElHamd et al., 2021).

Building on relationship marketing theory, the primary objective of this study is to investigate the factors affecting customer lifetime value (CLV), namely technical quality, functional quality, brand credibility, confidence benefits, special treatment benefits, customer satisfaction and commitment in the internet service providers in the Middle East, particularly in Jordan. Therefore, to further understand the internet service market, it is crucial to investigate the core drivers of CLV. This approach can provide stakeholders with key insights that can potentially decrease the number of customers changing services and, protect against new entrants. In other words, this study offers key information and recommendations to help classify domains where specific developments are needed and highlight aspects of the business's CRM practice that need to be conducted more efficiently.

Previous studies have studied the antecedents of CLV and, primarily, the effects of satisfaction (Raza et al., 2020; Rust, 2020) and customer commitment on outcomes of CRM (Rather et al., 2019; Rather, 2018). Service quality was linked to customer satisfaction and commitment (Lee and Seong, 2020; Huang et al.,2019). Previous studies have also found that relational benefits are 
important antecedents of customer commitment and customer satisfaction (Jamshidi and Rousta, 2021; Gremler et al., 2020). In the current research, service quality measured as a construct with two-dimensions, functional and technical service quality dimensions (Grönroos, 1984; Dagger and Sweeney, 2006), and relational benefits classified in this study into three different advantage kinds:

confidence benefits, special treatment benefits (Hennig-Thurau et al., 2002) and credibility (Sweeney and Swait, 2008), to improve the study's diagnostic value. Few studies have been done to empirically examine all these dimensions together in one model within the context of services. Consequently, this study fills this gap by establishing a research model that considers functional quality, technical quality, brand credibility, confidence benefits, special treatment benefits, customer satisfaction, commitment, and customer lifetime value in the internet service providers. Thus, the following set of questions has been raised:

Q1. What are the impacts of relational benefits and service quality dimensions on customer satisfaction, commitment, and, conclusively, CLV?

Q2. Which of the relational benefits and service quality dimensions will have the most significant impact on customer commitment and customer satisfaction?

Q3. What recommendations can be implemented on the executive level to enhance CLV?

\section{Conceptualising Customer Lifetime Value (CLV)}

Lifetime value (LTV), which can be also defined as customer lifetime value (CLV), is a measure of the customer segment's profit generation for a business. Lifetime value can be defined as the present-day value of the net profit margin received from a relationship with a cohort, customer or customer segment (Buttle and Maklan, 2019, p.35). Regularly, the CLV of a customer for a business can be considered as the net revenues acquired from the customer over his lifetime of transactions by that customer minus attraction costs, selling costs, and the costs of serving that customer, taking into considerations the time value of money (Qi et al., 2012). For businesses, CLV holds a key role in attracting investors as long-term CLV represents steadier future cash flows generated by loyal existing customers and newly-acquired customers (McCarthy, Fader, \& Hardie, 2017). Similarly, successful CRM contributes to revenues positively due to cross-selling activities, increased customers penetration rates (Hennig-Thurau et al., 2002). Companies use CRM tools for various reasons such as growth stimulation for their revenues and customers or improvement in customer loyalty and acquisition (Dalla Pozza, Goetz, \& Sahut, 2018). An empirical study by Li, Huang, and Song (2019) show that CRM has significant operational benefits that improve customer satisfaction and leads to higher profitability. 
Although CLV is typically defined and calculated on an individual basis, which helps firms differentiate customers who are more profitable to firms, accurately estimating the revenues and costs of a relationship remains challenging. In theory, CLV represents the margin between how much a firm spends to acquire each customer and the associated value in monetary terms (Chen, 2012; Sohrabi and Khanlari, 2007). Firms can compute it for individual customers from their purchases history and estimate individual customers' benefit, allocate promotions and distribute organisational resources for customer retention. However, it is difficult to make accurate calculations of it (Chen, 2012). Though several scholars have placed great emphasis on the financial perspective of CLV, most are theoretical, complex and not applicable (Sohrabi and Khanlari, 2007; Chen, 2012). To assess CLV, a business should identify the main factors that will lead to the maximization of CLV (Segarra-Moliner and Moliner-Tena, 2016). Therefore, CLV is not only a financial index but also a marketing index (Chen, 2012). According to Hughes (1994) and Mcdonald (1996), CLV can be measured from a marketing index (cited by Chen, 2012), including core relations (attitudinal loyalty) and extend connections (behavioural loyalty and word of mouth). Therefore, this study will adopt a marketing index approach and examine which factors would affect CLV instead of its calculation

\section{Internet service provider in Jordan}

Worldwide, the Information and Communications Technology (ICT) division is an essential facilitator of societal and economic development, fostering an inclusive digital economy and linking the digital divide. The stable internet market in the MENA region is starting slowly to be stronger amid other more developed markets, with a penetration rate of 64.5 in the region and 3.9 per cent of the internet users globally (Akroush and Mahadin, 2019). The ICT division has witnessed major growth throughout the years. It is an economic pillar of Jordan, offering employment for only 1 per cent of the overall population, however, 14 per cent of the national GDP is contributed by it (Akroush and Mahadin, 2019). By 2015 the total revenues of the telecommunication sector have exceeded US\$1.35bn, while the ICT income had grown to exceed US $\$ 600 \mathrm{~m}$. According to the Broadband Internet Subscriber Index for 2015, Jordan has advanced by six points when compared to 2014, ranking it 85 out of 139 countries (Akroush and Mahadin, 2019).

On the other hand, e-commerce plays a vital role in developing and developed countries and consequently Jordan`s economy, a recent study by Hussein and Baharudin (2017, p. 115) found that the internet plays an important role in small and medium businesses adapting e-commerce in Jordan. Also, it was found out that internet technology that can be utilized in CRM significantly improve customer satisfaction, loyalty, retention and value (Nikhashemi et al., 2013). 
There are currently three major internet operators in Jordan, Orange, Zain and Umniah. In 2020, the devastating effects of the COVID-19 pandemic severely impacted the telecommunications industry globally; as the outbreak has undesirably affected economies which lead to a lower customers expenditure over their products and services overall, that lead to increased competition among telecommunication organisations in general and the internet service providers in specific. Jordan is no exception, as each internet service provider is eager to gain as well as keeping its current customers.

The strategic location and developed telecommunication sector have made Jordan a pioneering destination in the MENA region for information technology businesses and startups, therefore getting exceptional governmental attention (About Jordan - Minister of Digital Economy and Entrepreneurship, 2020). William Cohan is describing it as the "MENA silicon valley "(Cohan, 2012). But the internet is not just a governmental interest. It is also the people's window to the world and considered a valuable source of information, news, entertainment and a new way of conducting business. As a result, we have witnessed increased popularity for internet usage. For instance, in 2012, 75\% of the Arabic content on the internet was produced in Jordan (Expansion of Jordan's ICT sector remains a government priority, 2015). According to the United States Central Intelligence Agency, almost $67 \%$ of the overall population in Jordan had access to the internet (Middle East: Jordan — The World Factbook - Central Intelligence Agency, 2018).

\section{Research model and hypotheses}

Using the research model presented in Figure 1, we will investigate the role of functional quality, technical quality, brand credibility, confidence benefits and special treatment benefits in enhancing customer satisfaction and commitment, which ultimately leads to CLV.

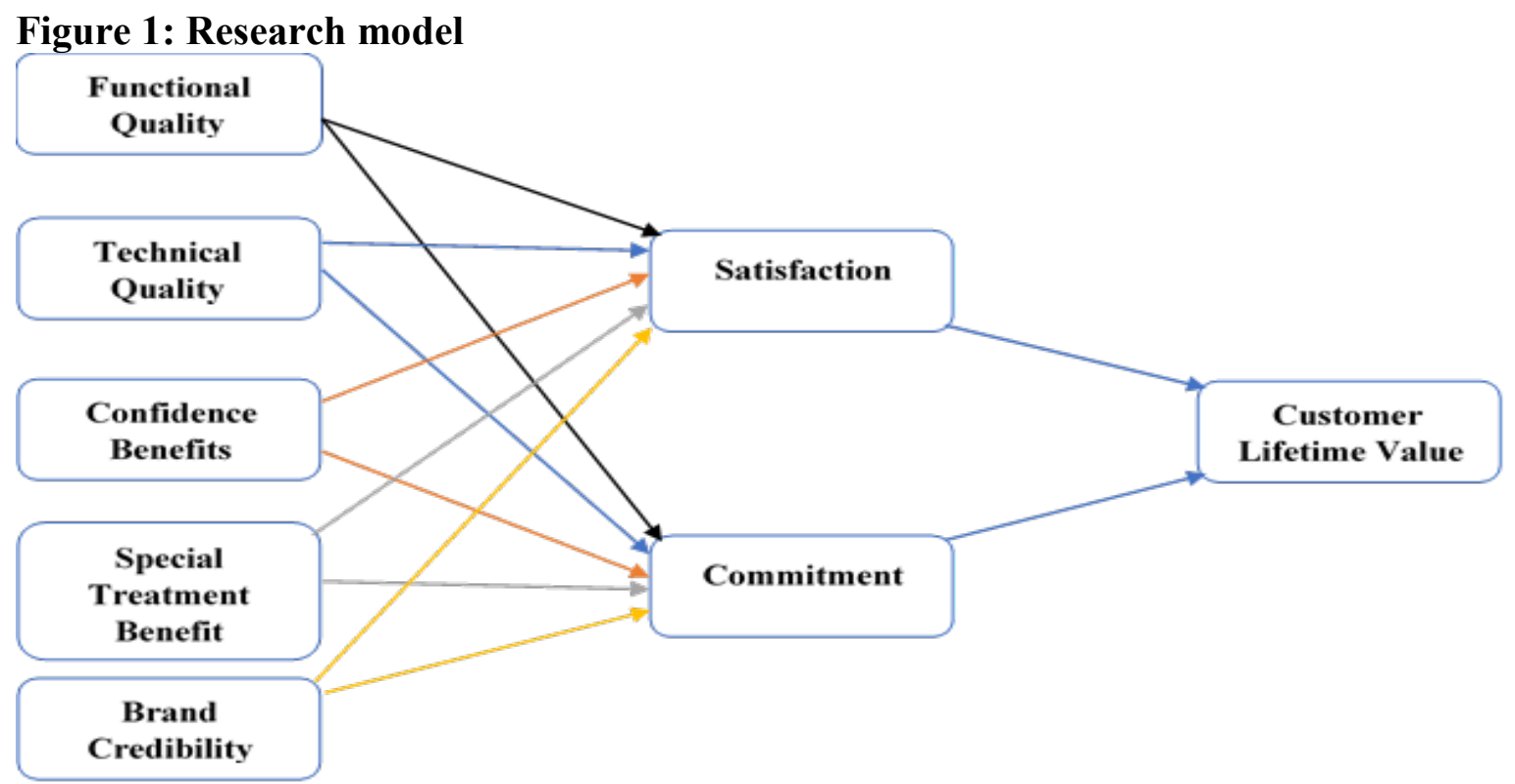




\section{Technical, Functional, Customer Satisfaction, and Commitment}

Service quality is a reflection of the overall assessment of the standard of service received and it has been discussed in the literature using mainly two models namely functional and technical quality model developed by Gronroos (1990) and Gap Model/SERVQUAL developed by Parasuraman et al. (1988). Even though SERVQUAL grabbed a lot of attention, but Gronroos' (1990) model is still not well studied and requires more elaboration (Ali et al., 2017). In other words, only a few studies examined the relationship between functional quality, technical quality and customer satisfaction (Kasiri et al., 2017; De Keyser \& Lariviere, 2014). In other words, quality from this perspective was put into effect based on its functional and technical aspects (Grönroos 1983; Aurier and N'Goala, 2009), as they play a critical role in customer relationships according to the marketing literature (Aurier and N'Goala, 2009; Dagger and Sweeney, 2006). Academics consider the technical and functional aspects as two distinct dimensions of service quality theoretically and endorse avoiding the construct to be viewed as unidimensional (Teeroovengadum et al., 2019).

The delivery process of the core service and the customer and service provider interactions is known as functional quality (Ng et al., 2011; Dagger and Sweeney, 2006). Functional benefits are vital in customers provided convenience, which can lead to saving them efforts and time when searching for information about a new product or when getting support with technical problems (Wong et al., 2019). Because of the increased competition among industries, businesses are focusing more on the core service offering and the inherent in service delivery the could potentially lead to enhanced customer perceptions ( $\mathrm{Ng}$ et al., 2011). Technical quality, in contrast, reflects what the customer receives as a result of service production or the overall outcome of the service experience (Ng et al., 2011; Dagger and Sweeney, 2006; Ali et al., 2017). For example, customers getting helpful advice from employees or customers perceiving their expectations to be met by the service performance. Technical quality tackles the know-how technical aspects and the reliability of customers expectations to receive and, in addition to the expertise of the service provider $(\mathrm{Ng}$ et al., 2011).

There are sample studies on customer satisfaction with its relationship with the service quality as a major construct (Özkan et al., 2019; Huang et al., 2019). Raza et al. (2020) and Joudeh (2017) found that all the dimensions had a significant and positive influence on the satisfaction of the customer. Similarly, Lee and Seong (2020) and Famiyeh et al. (2018) found that the majority of the business service quality dimensions can influence commitment and satisfaction; performance is positively affected by commitment and satisfaction (Seong, 2020). Research conducted in five Asian countries has shown the significant impact of a service quality model application to validate 
its influence on customer satisfaction and loyalty (Gong \& Yi, 2018). Kasiri et al. (2017) found that functional quality influence on satisfaction was higher than technical quality; also the influence of customer satisfaction on customer loyalty is significant. Therefore, this study suggests the following hypotheses:

Hypothesis 1: Functional quality is positively related to customer satisfaction.

Hypothesis 2: Functional quality is positively related to commitment.

Hypothesis 3: Technical quality is positively related to customer satisfaction.

Hypothesis 4: Technical quality is positively related to commitment.

\section{Confidence Benefits, Customer Satisfaction, and Commitment}

Concerning the customer value benefits, Gwinner et al., (1998) noticed that customer relational can possibly be classified into special treatment benefits and confidence benefits. Gwinner et al (1998) defined confidence benefits as "feelings of reduced anxiety, trust, and confidence in the provider" (p. 104). "It is a psychological benefit comprising feelings of comfort related to knowing what to expect during a service encounter that brings about feelings of security, anxiety reduction, trust, and confidence in service providers" (Wong et al., 2019, p.222).

The literature review supports modelling confidence benefits to be a driving factor over commitment and satisfaction. From the meta-analysis conducted by Gremler et al. (2020), existing research commonly examines relational benefits such as confidence and special treatment benefits in affecting perceived value, relationship quality or switching costs, and their research found that although relational benefits generally affect customer loyalty and confidence benefits generated the strongest effects. Fatima and Mascio (2020) also found that each type of relational benefits can also influence customers' behaviours with varying levels of commitment differently, where confidence benefits help customers adjust their expectations and, subsequently, their satisfaction. In the longer term, confidence benefits can positively affect and increase customer's trust, too (Chou \& Chen, 2018).

$\mathrm{Ng}$ et al. (2011) has confirmed that the most impactful construct on customer outcome behaviours is confidence benefits. Similarly, Meldrum and Kaczynski (2007) found that confidence benefits had significant predictors of relationship strength. Also, Hennig-Thurau et al. (2002) specified that the concepts of commitment, customer satisfaction, and confidence benefits significantly contribute to the outcomes of relationship marketing in services. Confidence benefits would have a positive influence on customers` commitment to the relationship (Hennig-Thurau et al., 2002). Previous studies also revealed the positive influence of confidence benefits on customer satisfaction (Fatima et al., 2016; Dagger and Brien, 2010); and confidence benefits toward 
commitment (Wong et al., 2019; Yang et al., 2017; Chou and Chen, 2018; Fatima et al., 2016). Therefore, this study suggests the following hypotheses:

Hypothesis 5: Confidence benefits are positively related to customer satisfaction.

Hypothesis 6: Confidence benefits are positively related to commitment.

\section{Special Treatment Benefits, Customer Satisfaction, and Commitment}

The widespread application of special treatment benefits, delivered as a part of relationship marketing programs is because of the expectancy of positive financial revenue (Hennig-Thurau et al., 2002). Special treatment benefit links economic benefits and personalized services that customers perceive these services include efficiency, discounts and extra services that are not available for the public, only to certain customers (Wong et al., 2019). In other words, when a business offers additional types of special treatment benefits (like customised services or economic savings) cognitive and/or emotional switching barriers are increased and can possibly lead to increased commitment and loyalty by customers (Hennig-Thurau et al., 2002; Dagger and Brien, 2010). Special treatment benefits occur when loyal customers are rewarded with price breaks, special deals, and faster or more customized service than customers with lower levels of relationship (Dagger and Brien, 2010; Meldrum and Kaczynski, 2007; Hennig-Thurau et al., 2002; Gwinner et al., 1998). In some circumstances, this is recognised by clients as special treatment (Gwinner et al., 1998). Further, special treatment benefits were moderately useful in an Asian country and in online environments, but less so in the particular context of the services literature (Fatima et al., 2018).

Generally, special treatment benefits contribute to the feeling of gratitudes (Chou \& Chen, 2018). Therefore, the strategic implementation of special treatment benefits can be effective, especially in maximizing the sense of prestige and exclusivity for committed customers (Fatima \& Mascio, 2020). However, findings from Gremler et al. (2020) suggests that there must be a careful application of special treatment benefits to invoke customer loyalty as customers may shift their loyalty elsewhere where the offers are better, and echoing a similar sentiment, Dagger and Brien (2010) suggested that highly experienced customers may continuously seek a higher level of benefits to be satisfied.

Dagger and Brien (2010) reported that special treatment benefits positively impact perceptions of satisfaction and commitment, and trust. Chou and Chen (2018) also found that special treatment benefits have a positive relationship with commitment. Hennig-Thurau et al. (2002) suggested that commitment is significantly affected by special treatment benefits, while satisfaction is not significantly affected by special treatment benefits. Fatima et al. (2016) found that special 
treatment benefit had an insignificant effect on satisfaction. Similarly, Yang et al. (2017) observed that special treatment benefits did not affect commitment. Therefore, based on the above point of views, the following hypotheses associated with special treatment benefits are proposed:

H7. Special treatment benefits are positively related to customer satisfaction.

H8. Special treatment benefits are positively related to commitment.

\section{Brand Credibility, Customer Satisfaction, and Commitment}

It is also essential to understand that the organization and its primary service brand are often synonymous (Sweeney and Swait, 2008). Building the credibility of a brand is known by customers to be a long-term and ongoing investment by the organisation; hence, they act towards the organisation as if it were posting forfeited bonds when their promises are not being kept (Sweeney and Swait, 2008). Erdem and Swait (2004, p. 192) define brand credibility as "the product's information in a brand believability". Brand credibility can be considered the primary cognitive evaluation of a brand's expertise and trust level. When this cognitive evaluation is saturated with compelling positive, brand experiences, customers are more likely to form a stronger connection to the brand (An et al., 2019).

In a CRM context, a critical factor in managing long-term relations with customers is brand credibility. Recent findings by Srivastava et al. (2020) and Shams et al., (2017) saw a significant and positive connection between purchase intention and brand credibility. Jamshidi and Rousta (2021) also found that the brand-consumer relationship depicted by the image and credibility of the brand significantly affects customer satisfaction. Sallam (2015) noticed that brand credibility positively affected brand commitment and in turn brand commitment significantly impacted customer's word of mouth communication. Cuong (2020) determined that brand credibility had a relatively significant positive effect on perceived value, purchase intention, and customer satisfaction. Dwivedi et al. (2019) also found that brand credibility significantly affects customer expectation, satisfaction, and, subsequently, attachment and commitment.

Bougoure et al. (2016) confirm that brand credibility is associated with increased perceived quality, decreased customer risk perceptions, information search and increased customer estimated utility. An et al., (2019) found that the credibility of a brand is of utmost importance to customers to develop a sense of cohesion with the brand and a sense of kinship with other customers of the same brand. Similarly, Othman et al. (2017) initiate a significant relation between brand credibility and customer satisfaction. This means that the higher the brand credibility, the more positive the service quality is perceived, and thus, it is more attractive than non-credible brands (An et al., 2019), and it draws more attention to customers (Junior et al., 2020). Because brands with high 
credibility will receive higher continuation commitment compared with brands with lower credibility (Sweeney and Swait, 2008), this reasoning leads to the main hypotheses of the formation:

Hypothesis 9: Brand credibility is positively related to customer satisfaction.

Hypothesis 10: Brand credibility is positively related to commitment.

\section{Customer Satisfaction, Commitment, and Customer Lifetime Value (CLV)}

Customer satisfaction is a crucial variable in marketing and the expected relationship marketing outcome (Sharifi and Esfidani, 2014) and it remains one of the most frequently researched concepts in marketing (Nicolas et al., 2020; Yi and Nataraajan, 2018). It has been defined as "the number of customers, or percentage of total customers, whose reported experience with a firm, its products, or its services (ratings) exceeds specified satisfaction goals" (Farris et al., 2010; p.57).

Most studies reinforce the idea that satisfied customers tend to view the business as less risky and therefore are willing to adopt additional products from the same company, leading to increased volume and frequency. Other benefits of satisfaction include customers loyalty, improved business reputation and decreased marketing costs (Curtis et al, 2011). It can also lead to a higher retention rate (Santouridis and Veraki, 2017), as they are considered essential tools for increasing customer lifetime value (Sweeney and Swait, 2008). Customer satisfaction is the stimulation of their customer's buying behaviour and can return a positive experience over businesses (Qi, 2012). Rust (2020) suggested the gravity of understanding customer satisfaction and CLV, especially with marketing strategies heavily focused on personalization. The relationship between customer retention and satisfaction has been the focus of much research, and studies show that satisfaction ramifications are strongly recognised at the extremes (Farris et al., 2010).

Commitment is considered among the critical components of a long-term relationship in marketing (Rather and Sharma, 2017; Rather, 2018). It is regarded as the pillar of relationship marketing by various researchers. This concept yields several customer outcomes that promote productivity, efficiency, and effectiveness (Rather, 2018). Gustafsson, Johnson, and Roos (2005) argued that in the context of CRM, commitment is a key competitive element in encouraging businesses to improve their efforts to gain customer satisfaction. Additionally, it is also essential to improve businesses' service quality to increase customer satisfaction (Min et al., 2013). It can also be defined as a psychological commitment that depends on a customer's sense of belongingness and identification toward a service provider (Bowden-Everson et al., 2013). Several researchers have also highlighted its vital role in creating and maintaining long-term relationships between different business partners (Rather, 2018). Furthermore, customer commitment can also be described as an 
exchange partner's willingness to uphold a crucial lasting relationship (Rather, 2018; HennigThurau et al., 2002).

The development of commitment has been strongly related to customer satisfaction (Rather and Sharma, 2017; Rather, 2018). In other words, customer commitment and satisfaction are considered as two dimensions of relationship quality and the main predictors of customer lifetime value (Qi, 2012). According to Kumar and Reinartz (2016), customer satisfaction can also be adopted as a proxy to customer perceived value. Customer satisfaction was first introduced into the CLV calculation in literature by Ho et al., (2006). It appears strange to ignore customers when estimating lifetime value since customer lifetime value is fundamentally attached to repeat purchase (Ho et al., 2006). In other words, customers tend to purchase at higher prices when they are satisfied compared to when they are dissatisfied (Ho et al., 2006). The profit motive is the main reason for companies to develop long-term relationships with their customers. Companies make great efforts to enhance customer lifetime value through a long-term relationship with customers because of the commercial benefits they yield, which has been evident through literature (Buttle and Maklan, 2019). The satisfaction-profit chain advocates that satisfied customers are probably to become loyal, and excellent business performance can lead to a high customer loyalty level (Buttle and Maklan, 2019).

Despite the belief of the positive impact of customer satisfaction over customer revenue and customer lifetime duration (Homburg et al., 2005), other researchers hold an opposing view: customer satisfaction can lead to positive purchase intention and preserve relationship intention. However, it cannot for certain produce subsequent purchase behaviour and non-defection behaviour (Chandrashekaran et al., 2007 cited by Qi et al., 2012). The situation is similar to customers commitment. While some researchers believe that loyalty commitment is a driver of CLV because of the more future purchases, in addition to a longer relationship duration, other researchers consider the effect of customer loyalty either overrated or simplified. In some cases, CLV can be positively impacted by customer loyalty, while in other cases, it cannot (Qi et al., 2012). Previous studies (Raza et al., 2020; Joudeh and Dandis,2018; Kasiri et al., 2016) also found that customer satisfaction has a significant effect on the outcomes of CRM. Additionally, scholars also pointed out that customer commitment had a significant influence over repurchase intentions (Keinningham et al., 2015; Su et al., 2016). Therefore, this study suggests the following hypotheses:

Hypothesis 11: Customer satisfaction is positively related to customer lifetime value.

Hypothesis 12: Commitment is positively related to customer lifetime value. 


\section{Methodology}

\section{Data and procedures}

An online survey was deployed using Google Forms. This method holds threefold advantages. First, it enables researchers to collect a reasonably large amount of data at a somewhat low cost (An et al., 2019; Neuman, 2014; Kotler et al., 2019; Schmidt and Hollensen, 2006). Second, the process of data collection is shorter, because online surveys can reach potential respondents immediately regardless of the geographic location (An et al., 2019; Neuman, 2014; Kotler et al., 2019) and lastly respondents can complete the questionnaire at a time of their preference (An et al., 2019). Online surveys were distributed via e-mail, and social media groups such as "Umniah internet, Orange clients ". Data collection was done during lockdown (a result of the global Covid219 pandemic) giving respondents plenty of time to fill the questionnaire and consequently providing a high response rate. Third, online survey methods prevent data entry errors (An et al., 2019). As the tool can be utilised with Arabic culture, the researchers then translated this questionnaire into the Arabic language with compliance to the Arabic language literature review, and the data collection was conducted from May 2020 to September 2020. After three months, we received 481 completed questionnaires, providing a high statistical power level (Bowden-Everson et al., 2013).

In this study, SPSS was selected for the data descriptive statistical analyses, multiple regression analysis, factor analysis and Pearson's correlation coefficient. PLS-SEM was used to offer robustness check and analyse discriminant validity and convergent validity and to test the proposed relationships. We measured all items of the survey instrument using five-point Likert scales. Table 2 provides details of the measurement items. 


\section{Results}

\section{Descriptive statistics}

Table 1 shows the characteristics of the research sample. As demonstrated, $81.3 \%$ of the respondent were males, and $18.7 \%$ were females, with the vast majority (68\%) with an Undergraduate education level. (44\%) The respondents are within the range age of eighteen to twenty-five; over (30\%) were aged twenty-six to thirty-five, and over $(20 \%)$ were older than thirtyfive. As displayed in Table 1, of the sample, the highest percentage monthly income below 300 Jordanian Dinars (300 JOD equivalent to 423 USD) (35.6\%). Other income levels reported are: 300 to $500(29.5 \%), 501$ to $1000(20.6 \%)$. The biggest number of respondents worked in professional occupations (38.7\%), such as lawyer, accountant, engineer, etc. They were followed by students with a percentage of $(28.9 \%)$.

Regarding the internet service providers, (37.8\%) of the respondents are dealing with Zain, followed by Orange with the percentage of (35.3\%), then Umniah with (26.8\%). The vast majority of the respondents $(42.6 \%)$ have been dealing with the same service providers for between one to three years. Similarly, (35.3\%) of the respondents have been loyal customers for more than five years. This means it is a great time judge and evaluates the service providers and any additional factor, such as special treatment benefits.

Table 1: Sample characteristics

\begin{tabular}{|c|l|c|c|}
\hline Factor & \multicolumn{1}{|c|}{ Item } & Frequency & Percentage \\
\hline \multirow{2}{*}{ Gender } & Male & 391 & 81.3 \\
& Female & 90 & 18.7 \\
\hline \multirow{5}{*}{ Education } & High school or less & 52 & 10.8 \\
& College & 50 & 68.4 \\
& Undergraduate & 327 & 10.8 \\
& Postgraduate & 52 & 1.0 \\
\hline \multirow{3}{*}{ Age } & Less than 18 & 5 & 44.1 \\
& $18-25$ & 212 & 30.8 \\
& $26-35$ & 148 & 21.8 \\
& $36-50$ & 105 & 2.3 \\
\hline \multirow{3}{*}{ Income (Month) } & 51 or more & 11 & 35.6 \\
& Less than 300 & 141 & 29.5 \\
& $300-500$ & 99 & 20.6 \\
\end{tabular}




\begin{tabular}{|l|l|c|c|}
\hline & Student & 139 & 28.9 \\
& Professional & 186 & 38.7 \\
\multicolumn{1}{|c|}{ Occupation } & Businessperson & 19 & 4.0 \\
& Retired & 10 & 2.1 \\
& Housewife & 5 & 1.0 \\
& Managerial & 68 & 14.1 \\
& Others & 54 & 11.2 \\
\hline Which of the following & Orange & 170 & 35.3 \\
service providers do you & Zain & 182 & 37.8 \\
deal with? & Umniah & 129 & 26.8 \\
\hline \multirow{2}{*}{ How long have you been } & Less than 1 year & 53 & 11.0 \\
dealing with this service & $1-3$ years & 205 & 42.6 \\
provide? & $4-5$ years & 53 & 11.0 \\
& More than 5 years & 170 & 35.3 \\
\hline
\end{tabular}

\section{Measurement Model}

Skewness and kurtosis were conducted to meet the criteria of multivariate normality. "The absolute value of skewness greater than 3.0 or the absolute value of kurtosis greater than 8.0 may indicate an abnormal distribution. Therefore, it was accepted that the value of skewness and kurtosis should not be greater than 3.0 and 8.0" (Chen 2012). This is supported by Dandis and Wright (2020). As shown in Table 2, the skewness and kurtosis values were within satisfactory levels, demonstrating the multivariate normality. 
Table 2: Skewness and kurtosis values of the variables

\begin{tabular}{|c|c|c|c|}
\hline No. & Statement & Skewness & Kurtosis \\
\hline & Confidence benefits (Dagger and O'Brien, 2010) & & \\
\hline 1. & I have more confidence the service will be performed correctly. & -.147 & -.898 \\
\hline 2. & I have less anxiety when I buy the service. & -.050 & -1.000 \\
\hline \multirow[t]{2}{*}{3.} & I get the service provider's highest level of service & .162 & -1.106 \\
\hline & \multicolumn{3}{|l|}{ Special treatment benefits (Dagger and O'Brien, 2010) } \\
\hline 4. & I get discounts or special deals that most customers do not get. & .722 & -.551 \\
\hline 5. & I get better prices than most customers & .915 & -.084 \\
\hline 6. & The service provider does services for me that they don't do for most customers. & .513 & -.764 \\
\hline \multirow[t]{2}{*}{7.} & I get faster service than most customers & .605 & -.618 \\
\hline & \multicolumn{3}{|l|}{ Functional quality (Ng et al., 2011) } \\
\hline 8. & The service provider is courteous. & -.754 & -.173 \\
\hline 9. & The service provider is willing to help me. & -.547 & -.410 \\
\hline 10. & The service provider gives me prompt service. & -.529 & -.439 \\
\hline \multirow{2}{*}{11.} & The service provider has excellent physical environment & -.718 & -.028 \\
\hline & \multicolumn{3}{|l|}{ Technical quality (Ng et al., 2011) } \\
\hline 12. & The service provider has the knowledge to answer my questions & -.517 & -.469 \\
\hline 13. & The service provider knows what they are talking about & -.554 & -.404 \\
\hline \multirow[t]{2}{*}{14.} & The service provider carries out their tasks competently & -.474 & -.493 \\
\hline & \multicolumn{3}{|l|}{ Brand credibility (Sweeney and Swait, 2008) } \\
\hline 15. & (Service brand) delivers what it promises & -.063 & -1.092 \\
\hline 16. & XXX's claims about its service are believable & -.112 & -.960 \\
\hline 17. & XXX has a name you can trust. & -.548 & -.623 \\
\hline 18. & XXX doesn't pretend to be something it isn't & -.315 & -.731 \\
\hline \multirow[t]{2}{*}{19.} & $\mathrm{XXX}$ is at the forefront of using technology to deliver a better service & -.596 & -.069 \\
\hline & Customer Satisfaction (Dagger and O’Brien, 2010) & & \\
\hline 20. & My choice you use this service provider was a wise one. & -.256 & -.931 \\
\hline 21. & Overall, I am satisfied with this service provider & -.620 & -.205 \\
\hline 22. & I think I did the right thing when I decided to use this service provider & -.187 & -1.049 \\
\hline \multirow[t]{2}{*}{23.} & I feel good about using this service provider & -.069 & -1.149 \\
\hline & \multicolumn{3}{|l|}{ Commitment (Dagger and O'Brien, 2010) } \\
\hline 24. & My relationship with the service provider is something I really care about & -.170 & -.913 \\
\hline 25. & $\begin{array}{l}\text { My relationship with the service provider deserves my maximum effort to } \\
\text { maintain }\end{array}$ & .083 & -.844 \\
\hline 26. & I have a strong sense of loyalty to this service provider & .208 & -1.143 \\
\hline 27. & $\begin{array}{l}\text { This service provider is prepared to make short term sacrifices to maintain our } \\
\text { relationship. }\end{array}$ & .365 & -.981 \\
\hline \multirow[t]{2}{*}{28.} & $\begin{array}{l}\text { I believe the service provider and I view our relationship as a long-term } \\
\text { partnership }\end{array}$ & .147 & -1.049 \\
\hline & \multicolumn{3}{|l|}{ Lifetime Value (Zeithaml et al.(1996) and Pritchard et al. (1999) } \\
\hline 29. & I will continue to do business with the service provider for the next several years. & -.115 & -1.091 \\
\hline 30. & $\begin{array}{l}\text { Even if close friends recommended another service provider, I would not change } \\
\text { my preference for this service provider. }\end{array}$ & .117 & -1.151 \\
\hline 31. & $\begin{array}{l}\text { I consider the service provider my first choice when I purchase the services they } \\
\text { supply. }\end{array}$ & -.088 & -1.096 \\
\hline 32. & $\begin{array}{l}\text { I prefer to deal with this service provider because their image comes closest to } \\
\text { reflecting my lifestyle. }\end{array}$ & -.004 & -1.076 \\
\hline 33. & $\begin{array}{l}\text { My decision to deal with this service provider was freely chosen from several } \\
\text { alternatives }\end{array}$ & -.453 & -.812 \\
\hline 34. & I say positive things about the service provider to other people & -.122 & -1.001 \\
\hline 35. & I recommend the service provider to someone who seeks my advice & -.133 & -1.064 \\
\hline 36. & I encourage friends and relatives to do business with the service provider & -.081 & -1.090 \\
\hline
\end{tabular}




\section{Factor analysis}

Factor analysis is a statistical method used with a large number of questions and reduces them into a smaller number of coherent subscales, prior to using them in other analyses such as multiple regression (Pallant, 2020; Aaker et al., 2013). However, factor loadings indicate what percentage of the variance in an original variable is explained by a factor. "Loadings can range from -1 to 1. Loadings close to -1 or 1 indicate that the factor strongly affects the variable. Loadings close to zero indicate that the factor has a weak effect on the variable". In this research, loading of \pm 0.40 or more considered to be acceptable (Malhotra et al., 2017). In addition, "one of the most commonly popular criteria was adopted to assess the suitability of the data is known as the KaiserMeyer-Olkin (KMO), and the eigenvalue rule. The KMO index ranges from 0 to 1(Pallant, 2020; Malhotra et al., 2017), with 0.5 suggested as the minimum value for a good factor analysis" (Malhotra et al., 2017). The eigenvalue of a factor represents the amount of the total variance explained by that factor. Only factors with an eigenvalue of 1.0 or more are retained for further investigation (Pallant, 2020; Malhotra et al., 2017; Aaker et al., 2013).

VARIMAX rotation was used with the primary component analysis was used on 36 items. In this study, the acceptable range of loading is \pm 0.40 or more (Malhotra et al. 2017). It is evident in Table 3, the, factor loadings for most of the items are greater than 0.4 . The overall range for factor loadings was $0.744-0.948$ for most items indicating that the factor strongly affects the variable (Malhotra et al., 2017). There was one exception that had a factor loading lower than 0.40 , thus it is considered a weak item in the construct. Item 2 had the lowest loading with -0.293 . The KMO statistic value range was 0.514 - 0.931, inferring factor analysis appropriateness (Malhotra et al. 2017). All measures of Cronbach's alpha exceeds 0.70 which is the recommended threshold value (Malhotra et al. 2017). Consequently, all measurements are robust with respect to their reliability. Table 3 presents a summary of the reliability test results and factor analysis. 
Table 3: Factor Analysis and Reliability Analysis Test

\begin{tabular}{|c|c|c|c|c|c|c|}
\hline Variable & $\begin{array}{l}\text { No. of } \\
\text { Item }\end{array}$ & $\begin{array}{l}\text { Factor } \\
\text { loadings }\end{array}$ & Eigenvalue & $\begin{array}{l}\% \text { of variance } \\
\text { explained }\end{array}$ & KMO & Cronbach's Alpha \\
\hline Confidence benefits & $\begin{array}{l}1 \\
2 \\
3\end{array}$ & $\begin{array}{r}.918 \\
-.293 \\
.918\end{array}$ & 1.772 & 59.061 & .514 & .844 \\
\hline $\begin{array}{l}\text { Special treatment } \\
\text { benefits }\end{array}$ & $\begin{array}{l}4 \\
5 \\
6 \\
7\end{array}$ & $\begin{array}{l}.885 \\
.892 \\
.798 \\
.835\end{array}$ & 2.915 & 72.873 & .783 & .875 \\
\hline Functional quality & $\begin{array}{c}8 \\
9 \\
10 \\
11\end{array}$ & $\begin{array}{l}.852 \\
.925 \\
.895 \\
.744\end{array}$ & 2.936 & 73.398 & .796 & .878 \\
\hline Technical quality & $\begin{array}{l}12 \\
13 \\
14\end{array}$ & $\begin{array}{l}.941 \\
.926 \\
.929\end{array}$ & 2.606 & 86.864 & .761 & .924 \\
\hline Brand credibility & $\begin{array}{l}15 \\
16 \\
17 \\
18 \\
19\end{array}$ & $\begin{array}{l}.860 \\
.877 \\
.876 \\
.853 \\
.762\end{array}$ & 3.586 & 71.720 & .877 & .901 \\
\hline Satisfaction & $\begin{array}{l}20 \\
21 \\
22 \\
23\end{array}$ & $\begin{array}{l}.925 \\
.835 \\
.948 \\
.934\end{array}$ & 3.323 & 83.065 & .847 & .932 \\
\hline Commitment & $\begin{array}{l}24 \\
25 \\
26 \\
27 \\
28\end{array}$ & $\begin{array}{l}.863 \\
.881 \\
.883 \\
.836 \\
.896\end{array}$ & 3.802 & 76.045 & .872 & .921 \\
\hline Lifetime value & $\begin{array}{l}29 \\
30 \\
31 \\
32 \\
33 \\
34 \\
35 \\
36\end{array}$ & $\begin{array}{l} \\
.897 \\
.886 \\
.919 \\
.905 \\
.756 \\
.898 \\
.912 \\
.932\end{array}$ & 6.332 & 79.144 & .931 & .962 \\
\hline
\end{tabular}




\section{Data Analysis}

Table 4 presents the preliminary test of the hypotheses through the correlations between the studied constructs. The five independent variables "confidence benefits, brand credibility, special treatment benefits, technical quality, functional quality" are positively correlated with commitment, customer satisfaction, and lifetime value, with brand credibility, appear to have the highest positive of satisfaction (0.807), and commitment (0.754). Additionally, satisfaction (0.862) and commitment (0.858) as independent variables had a strong positive correlation was found between them, with lifetime value. The hypotheses put forward are confirmed, based on the correlation coefficients.

Table 4: Correlation matrix

\begin{tabular}{|l|l|l|l|l|l|l|l|l|}
\hline & $\mathbf{( 1 )}$ & $\mathbf{( 2 )}$ & $\mathbf{( 3 )}$ & $\mathbf{( 4 )}$ & $\mathbf{( 5 )}$ & $\mathbf{( 6 )}$ & $\mathbf{( 7 )}$ & $\mathbf{( 8 )}$ \\
\hline (1) Confidence benefits & 1 & $.663^{* *}$ & $.587^{* *}$ & $.596^{* *}$ & $.781^{* *}$ & $.776^{* *}$ & $.721^{* *}$ & $.747^{* *}$ \\
\hline (2) Special treatment benefits & $.663^{* *}$ & 1 & $.481^{* *}$ & $.513^{* *}$ & $.629^{* *}$ & $.615^{* *}$ & $.648^{* *}$ & $.586^{* *}$ \\
\hline (3) Functional quality & $.587^{* *}$ & $.481^{* *}$ & 1 & $.807^{* *}$ & $.746^{* *}$ & $.637^{* *}$ & $.538^{* *}$ & $.582^{* *}$ \\
\hline (4) Technical quality & $.596^{* *}$ & $.513^{* *}$ & $.807^{* *}$ & 1 & $.773^{* *}$ & $.658^{* *}$ & $.606^{* *}$ & $.590^{* *}$ \\
\hline (5) Brand credibility & $.781^{* *}$ & $.629^{* *}$ & $.746^{* *}$ & $.773^{* *}$ & 1 & $.807^{* *}$ & $.745^{* *}$ & $.760^{* *}$ \\
\hline (6) Customer Satisfaction & $.776^{* *}$ & $.615^{* *}$ & $.637^{* *}$ & $.658^{* *}$ & $.807^{* *}$ & 1 & $.824^{* *}$ & $.862^{* *}$ \\
\hline (7) Commitment & $.721^{* *}$ & $.648^{* *}$ & $.538^{* *}$ & $.606^{* *}$ & $.745^{* *}$ & $.824^{* *}$ & 1 & $.858^{* *}$ \\
\hline (8) Lifetime Value & $.747^{* *}$ & $.586^{* *}$ & $.582^{* *}$ & $.590^{* *}$ & $.760^{* *}$ & $.862^{* *}$ & $.858^{* *}$ & 1 \\
\hline
\end{tabular}

$*(* *)$ Significant level of correlation at $0.05(0.01)$ level (two-tailed, person).

\section{Hypotheses testing}

Evaluation of the measurement model offered an indication of validity and reliability. The model was studied to test the hypothesized relationships between the constructs (Agag and El-Masry 2017). The following represents multiple regression tests and hierarchical multiple regressions that were conducted:

1. As evident in table 5, customer satisfaction is designed to be the dependent variable, while confidence benefits, special treatment benefits, functional quality, technical quality and brand credibility are designated to be independent variables.

\section{Table 5: Impact of independent variables on customer satisfaction}

\begin{tabular}{|c|c|c|c|c|c|}
\hline \multirow[b]{2}{*}{ Model } & \multicolumn{2}{|c|}{ Unstandardized Coefficients } & \multirow{2}{*}{$\begin{array}{c}\text { Standardized Coefficients } \\
\text { Beta } \\
\end{array}$} & \multirow[b]{2}{*}{$\mathbf{t}$} & \multirow[b]{2}{*}{ Sig. } \\
\hline & B & Std. Error & & & \\
\hline Confidence benefits & .329 & .040 & .342 & 8.120 & .000 \\
\hline Special treatment benefits & .083 & .036 & .077 & 2.282 & .023 \\
\hline Functional quality & .047 & .051 & .041 & .928 & .354 \\
\hline Technical quality & .067 & .049 & .063 & 1.359 & .175 \\
\hline Brand credibility & .454 & .057 & .412 & 7.939 & .000 \\
\hline
\end{tabular}

* Dependent Variable: Satisfaction; R Square: 0.845; Adjusted R Square: 0.713 
As displayed in Table 6, three main dimensions of the independent variables that includes (1) confidence benefits, $t=8.120, p<0.05$ ( $p=0.000)$; (2) special treatment benefits, $t=2.282, p<$ 0.05 ( $p=0.023)$; and (3) brand credibility, $t=7.939, p<0.05(p=0.000)$, were found positively and significantly contributers to customer satisfaction prediction. An insignificant relationship between functional quality, $t=.928, p<0.05$ ( $p=0.354)$; technical quality, $t=1.359, p<0.05(p=$ 0.175 ) and customer satisfaction were found.

Meanwhile, amongst these main dimensions, brand credibility (Beta: 0.412) was found to be the most effective factor leading to customer satisfaction, followed by confidence benefits (Beta: 0.342), and special treatment benefits (Beta: 0.077).

2. As evident in table 6, technical quality, functional quality, confidence benefits, special treatment benefits and brand credibility are designated to be independent variables while customer commitment is the dependent variable.

Table 6: Impact of independent variables on commitment

\begin{tabular}{|c|c|c|c|c|c|}
\hline \multirow[b]{2}{*}{ Model } & \multicolumn{2}{|c|}{ Unstandardized Coefficients } & \multirow{2}{*}{$\begin{array}{c}\text { Standardized Coefficients } \\
\text { Beta } \\
\end{array}$} & \multirow[b]{2}{*}{$\mathbf{t}$} & \multirow[b]{2}{*}{ Sig. } \\
\hline & B & Std. Error & & & \\
\hline Confidence benefits & .250 & .044 & .265 & 5.612 & .000 \\
\hline Special treatment benefits & .228 & .040 & .216 & 5.682 & .000 \\
\hline Functional quality & -.135 & .056 & -.120 & -2.425 & .016 \\
\hline Technical quality & .139 & .054 & .135 & 2.589 & .010 \\
\hline Brand credibility & .417 & .063 & .387 & 6.631 & .000 \\
\hline
\end{tabular}

* Dependent Variable: Commitment; R Square: 0.798; Adjusted R Square: 0.634

As displayed in Table 6, five main dimensions of the independent variables including (1) confidence benefits, $t=5.612, p<0.05$ ( $p=0.000)$; (2) special treatment benefits, $t=5.682, p<$ 0.05 ( $p=0.000)$; (3) functional quality, $t=-2.425, p<0.05(p=0.016)$; (4) technical quality, $t=$ 2.589, $p<0.05(p=0.010)$; and (3) brand credibility, $t=6.631, p<0.05(p=0.000)$, were found positively and significantly contributers to customer commitment prediction.

Meanwhile, amongst these main dimensions, brand credibility (Beta: 0.387) was found to be the most influential factor leading to customer commitment, followed by confidence benefits (Beta: 0.265), and special treatment benefits (Beta: 0.216). 
3. As evident in table 7, customer satisfaction and customer commitment are designated to be independent variables while customer lifetime value is the dependent variable.

Table 7: Impact of commitment and customer satisfaction on customer lifetime value

\begin{tabular}{|c|c|c|c|c|c|c|}
\hline \multirow[b]{2}{*}{ Model } & & \multicolumn{2}{|c|}{ Unstandardized Coefficients } & \multirow{2}{*}{$\begin{array}{c}\text { Standardized Coefficients } \\
\text { Beta } \\
\end{array}$} & \multirow[b]{2}{*}{$\mathbf{t}$} & \multirow[b]{2}{*}{ Sig. } \\
\hline & & B & Std. Error & & & \\
\hline & Satisfaction & .491 & .036 & .482 & 13.780 & .000 \\
\hline & Commitment & .480 & .036 & .461 & 13.165 & .000 \\
\hline
\end{tabular}

a. Dependent Variable: customer lifetime value; R Square: 0.901; Adjusted R Square: 0.811

As displayed in Table 7, two main dimensions of the independent variables including (1) customer satisfaction, $t=13.780, p<0.05(p=0.000)$; and (2) customer commitment, $t=13.165, p<0.05$ $(p=0.000)$, were found positive and significant contributors to the overall prediction of customer lifetime value, with customer satisfaction (Beta: 0.482) emerging as the strongest predictor than customer satisfaction (Beta: 0.461).

\section{Robustness checks}

To guarantee the suitability of the statistical tools used in this research, structural equation modelling using SmartPLS was conducted, the analysis consisted of a measurement model and path coefficients. The first assessment was for the substantive constructs Cronbach's alpha, and all results exceeded the accepted threshold of .7 (Malhotra et al. 2017). To evaluate the convergent validity of the measures, the average variance (AVE) was extracted. The AVE of all measured items exceeded the satisfactory level of .5 (Hulland, 1999). Then the internal consistency of the measures was assessed by the execution of the composite reliability test. As displayed in Table 8 , all measures composite reliability exceeded the satisfactory level of .7 (Hair et al., 2013).

Table 8: Construct Reliability and Validity

\begin{tabular}{|l|c|c|c|}
\hline & Cronbach's Alpha & Composite Reliability & $\begin{array}{c}\text { Average Variance } \\
\text { Extracted (AVE) }\end{array}$ \\
\hline Brand Credibility & 0.901 & 0.927 & 0.717 \\
\hline Commitment & 0.921 & 0.941 & 0.760 \\
\hline Confidence Benefit & 0.846 & 0.928 & 0.866 \\
\hline Customer Lifetime Value & 0.962 & 0.968 & 0.791 \\
\hline Functional Quality & 0.877 & 0.916 & 0.733 \\
\hline Satisfaction & 0.931 & 0.951 & 0.831 \\
\hline Special Treatment & 0.875 & 0.914 & 0.728 \\
\hline Technical Quality & 0.924 & 0.952 & 0.869 \\
\hline
\end{tabular}


Table 9 shows the square root of the AVE, to examine the discriminant validity of the measures. It is clear that the scores are the highest in related rows and columns, indicating satisfactory discriminant validity of the measures (Birkinshaw et al., 1995).

Table 9: Latent Variable Correlation

\begin{tabular}{|l|c|c|c|c|c|c|c|c|}
\hline & $\mathbf{( 1 )}$ & $\mathbf{( 2 )}$ & $\mathbf{( 3 )}$ & $\mathbf{( 4 )}$ & $\mathbf{( 5 )}$ & $\mathbf{( 6 )}$ & (7) & (8) \\
\hline Brand Credibility (1) & 0.847 & & & & & & & \\
\hline Commitment (2) & 0.747 & 0.872 & & & & & & \\
\hline Confidence Benefit (3) & 0.782 & 0.721 & 0.931 & & & & & \\
\hline $\begin{array}{l}\text { Customer Lifetime } \\
\text { Value (4) }\end{array}$ & 0.761 & 0.862 & 0.749 & 0.89 & & & & \\
\hline Functional Quality (5) & 0.751 & 0.548 & 0.593 & 0.588 & 0.856 & & & \\
\hline Satisfaction (6) & 0.807 & 0.825 & 0.776 & 0.863 & 0.645 & 0.911 & & \\
\hline Special Treatment (7) & 0.635 & 0.651 & 0.668 & 0.593 & 0.488 & 0.62 & 0.853 & \\
\hline Technical Quality (8) & 0.771 & 0.608 & 0.597 & 0.589 & 0.81 & 0.659 & 0.516 & 0.932 \\
\hline
\end{tabular}

Path coefficients were used to examine the hypothesized relationships and proposed model, as shown in Table 10 and Figure 2. The findings show that all but two of the research hypotheses are supported (excluding $\mathrm{H} 1$ and H3). Functional quality has a positive but non-significant effect on satisfaction $(\beta=0.05, \mathrm{t}=0.986, \mathrm{p}=0.325)$, not providing support for hypothesis $\mathrm{H} 1$. Functional quality has a negative significant effect on commitment $(\beta=-0.105, \mathrm{t}=2.166, \mathrm{p}=0.031)$ providing support for hypotheses H2. Technical quality has a positive but non-significant effect on satisfaction $(\beta=0.061, \mathrm{t}=1.145, \mathrm{p}=0.253)$, not providing support for hypothesis $\mathrm{H} 3$. Technical quality has a positive significant effect on commitment $(\beta=0.128, \mathrm{t}=2.559, \mathrm{p}=0.011)$ providing support for hypotheses H4.

Confidence benefits has a positive significant effect on satisfaction $(\beta=0.338, t=7.148, p=0)$, and commitment $(\beta=0.259, \mathrm{t}=4.649, \mathrm{p}=0)$, providing support for hypotheses H5 and H6. Special treatment benefits has a positive significant effect on satisfaction $(\beta=0.08, t=2.236, p=0.026)$, and commitment $(\beta=0.218, \mathrm{t}=5.719, \mathrm{p}=0)$, providing support for hypotheses $\mathrm{H} 7$ and $\mathrm{H} 8$. Brand Credibility has a positive significant effect on satisfaction $(\beta=0.407, \mathrm{t}=6.623, \mathrm{p}=0)$, and commitment $(\beta=0.387, \mathrm{t}=5.917, \mathrm{p}=0)$, providing support for hypotheses $\mathrm{H} 9$ and $\mathrm{H} 10$.

Satisfaction has a positive significant effect on customer lifetime value $(\beta=0.477, \mathrm{t}=11.323, \mathrm{p}=$ $0)$, and commitment has a positive significant effect on Customer Lifetime Value $(\beta=0.468, \mathrm{t}=$ $10.85, \mathrm{p}=0$ ), providing support for hypotheses H11 and H12.

In sum, the structural findings indicate that brand credibility exerted a stronger effect on satisfaction, followed by confidence benefits and special treatment benefits respectively. Similarly, brand credibility exerted a stronger effect on commitment, followed by confidence benefits and special treatment benefits respectively. Whereas technical quality exerted the weakest 
positive effect and functional quality exerted a negative effect on commitment. satisfaction has a stronger effect on customer lifetime value than commitment.

Table 10: Hypothesis Testing

\begin{tabular}{|c|c|c|c|c|c|c|}
\hline & & $\begin{array}{c}\text { Original } \\
\text { Sample } \\
(0) \\
\end{array}$ & $\begin{array}{c}\text { Sample } \\
\text { Mean (M) }\end{array}$ & $\begin{array}{l}\text { Standard } \\
\text { Deviation } \\
\text { (STDEV) } \\
\end{array}$ & $\begin{array}{c}\text { T Statistics } \\
(|\mathrm{O} / \mathrm{STDEV}|)\end{array}$ & P Values \\
\hline H1 & $\begin{array}{l}\text { Functional Quality -> } \\
\text { Satisfaction }\end{array}$ & 0.05 & 0.052 & 0.051 & 0.986 & 0.325 \\
\hline H2 & $\begin{array}{l}\text { Functional Quality -> } \\
\text { Commitment }\end{array}$ & -0.105 & -0.104 & 0.049 & 2.166 & 0.031 \\
\hline H3 & $\begin{array}{l}\text { Technical Quality -> } \\
\text { Satisfaction }\end{array}$ & 0.061 & 0.064 & 0.054 & 1.145 & 0.253 \\
\hline H4 & $\begin{array}{l}\text { Technical Quality -> } \\
\text { Commitment }\end{array}$ & 0.128 & 0.13 & 0.05 & 2.559 & 0.011 \\
\hline H5 & $\begin{array}{l}\text { Confidence Benefit -> } \\
\text { Satisfaction }\end{array}$ & 0.338 & 0.338 & 0.047 & 7.148 & 0 \\
\hline H6 & $\begin{array}{l}\text { Confidence Benefit -> } \\
\text { Commitment }\end{array}$ & 0.259 & 0.258 & 0.056 & 4.649 & 0 \\
\hline H7 & $\begin{array}{l}\text { Special Treatment -> } \\
\text { Satisfaction }\end{array}$ & 0.08 & 0.077 & 0.036 & 2.236 & 0.026 \\
\hline H8 & $\begin{array}{l}\text { Special Treatment -> } \\
\text { Commitment }\end{array}$ & 0.218 & 0.217 & 0.038 & 5.719 & 0 \\
\hline H9 & $\begin{array}{l}\text { Brand Credibility }-> \\
\text { Satisfaction }\end{array}$ & 0.407 & 0.407 & 0.061 & 6.623 & 0 \\
\hline H10 & $\begin{array}{l}\text { Brand Credibility -> } \\
\text { Commitment }\end{array}$ & 0.387 & 0.386 & 0.065 & 5.917 & 0 \\
\hline H11 & $\begin{array}{l}\text { Satisfaction -> } \\
\text { Customer Lifetime } \\
\text { Value }\end{array}$ & 0.477 & 0.477 & 0.042 & 11.323 & 0 \\
\hline H12 & $\begin{array}{l}\text { Commitment -> } \\
\text { Customer Lifetime } \\
\text { Value }\end{array}$ & 0.468 & 0.469 & 0.043 & 10.85 & 0 \\
\hline
\end{tabular}

Results were reported in the robustness check were to a large extent consistent with the previous results reported in our findings earlier. This comparison assessment reduced our concern for the appropriateness of the measurement model and potential alternative clarifications for our dependent variable. 
Figure 2 Empirical model- factors affecting customer lifetime value

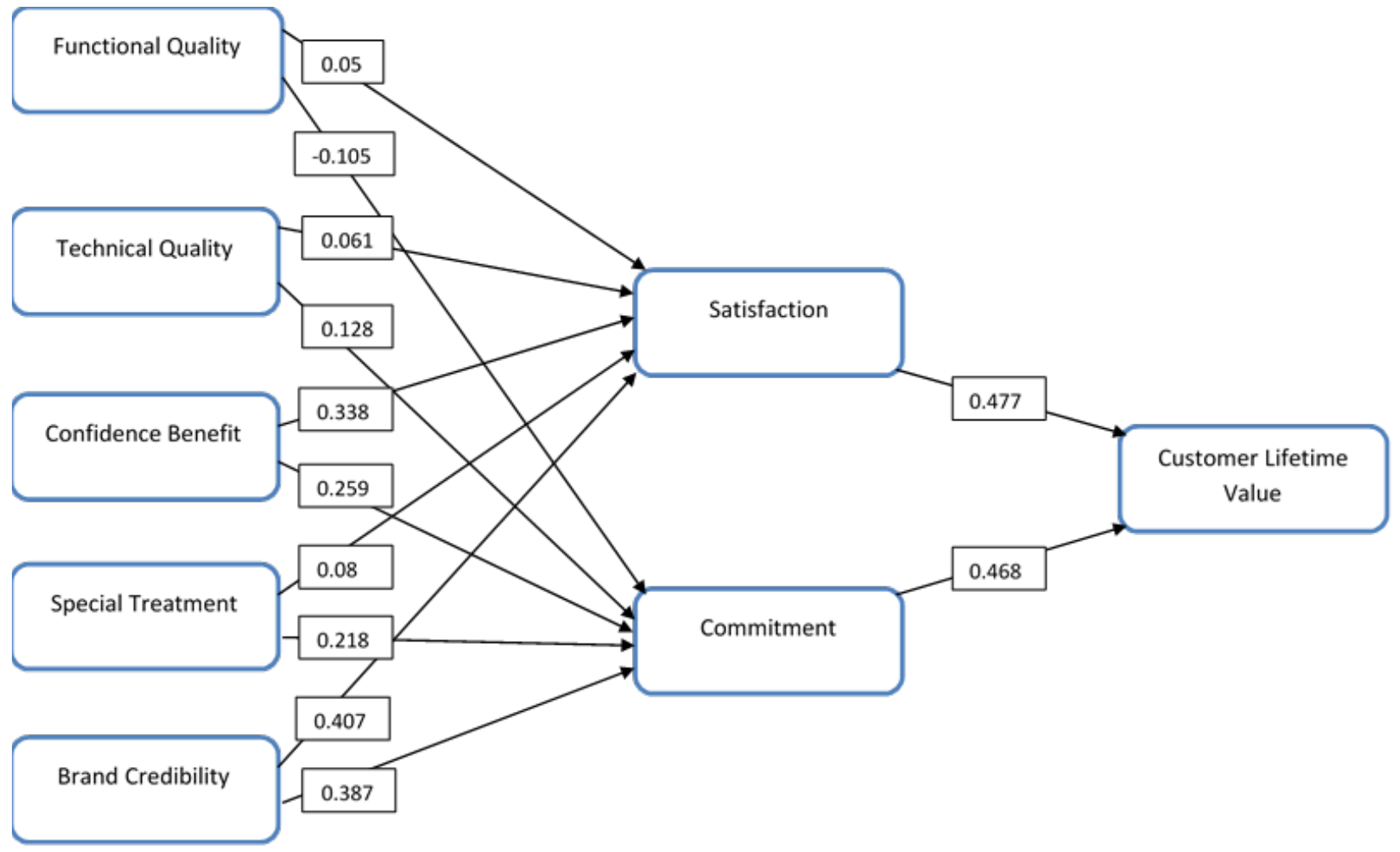

\section{Conclusion and discussion}

The main objective of this paper is to investigate the factors affecting customer lifetime value (CLV) for internet service providers in Jordan, namely technical quality, functional quality, brand credibility, confidence benefits, special treatment benefits, customer satisfaction and commitment. In this study, the first hypothesis examines whether there is a positive relationship between functional quality and customer satisfaction. Results showed an insignificant relationship between functional quality and customer satisfaction. This finding is different from past studies (Raza et al., 2020; Lee and Seongl, 2020; Huang et al. 2019; Gong \& Yi, 2018; Famiyeh et al.,2018) which found a significant relationship between these two variables. This finding also is not consistent with $\mathrm{Ng}$ et al. (2011), which reported that technical quality relates more to the intangible and challenging to assess service provision components. In contrast, functional quality is much easier for consumers to assess and thus make recommendations and comment on.

Similarly, the third hypothesis examines whether there is a positive relationship between technical quality and customer satisfaction. Findings also showed an insignificant relationship among these constructs (Sig. value $=0.175)$. This is supported by Ng et al. (2011), which reported that technical quality did not have any effect on the customer's intentions to say positive things about the service provider. However, this finding is different from past studies (Gong and Yi, 2018; Ali et al., 2017; 
Thaichon and Quach, 2015) which found a positive relationship between service quality (functional and technical quality) and customer satisfaction. A possible explanation could be that service quality is more difficult to measure and define than product quality, because of the inherent intangible nature of services, which are usually experienced subjectively (Grönroos, 1991). Another possible explanation is that the technical quality and functional quality of the internet service providers in Jordan could be perceived by their customers to be homogenous and could not be seen by customers as distinguishing the service providers (Akroush and Mahadin, 2019). Regarding service quality, we used the technical and functional quality, and scale components derived from $\mathrm{Ng}$ et al. (2011). The measurement scale examined in a variety of services contexts, namely general banking, airlines, fast-food outlets, family doctors, travel agents, fast-food outlets, cinemas, hairdressers, photo printing service and pest control, and they found to be robust. All items found to serve as strong measures of their respective constructs. This implies that these items to measure technical and functional quality which are relevant to the present research. However, it can be concluded that the effect of technical and functional quality on customer satisfaction various from one industry to another and from culture to culture. Therefore, the insignificant effect of the service quality dimensions on customer satisfaction and commitment specifically requires further investigation. As a result, technical quality and functional quality could not contribute to customer satisfaction. Therefore, the results reject the first and third hypothesis.

The second hypothesis examines whether there is a positive relationship between functional quality and commitment. Results indicate a significant positive relationship between functional quality and commitment. Similarly, the fourth hypothesis examines whether there is a positive relationship between technical quality and commitment. Results also indicate a significant positive relationship among them. This is in line with (Lee and Seong, 2020; Arcand et al.(2017) which found a significant relationship between these two variables. Despite having a meaningful positive relationship with commitment, functional and technical quality remain the least influential factors leading to customer commitment. This confirms our proposition of the undifferentiated service quality among the different service providers, which means changes in any of them will lead to slight changes in customers commitment, and this supports (Oh et al., 2011; Park et al., 2012). Functional and technical service quality is associated with the customers' commitment; likewise, within the internet service providers domain (Akroush and Mahadin, 2019; Thaichon and Quach, 2015).

The fifth and sixth hypothesis are supported by the results indicating that confidence benefits lead to more satisfied customers and a more committed to the organisation customers. These findings confirm the various empirical studies (Wong et al., 2019; Yang et al., 2017; Chou and Chen, 2018; 
Fatima et al., 2016) which found a significant relationship between these variables. Also, Dagger and Brien (2010) and Gwinner et al. (1998) reported that confidence benefits significantly affected satisfaction and commitment. Hennig-Thurau et al. (2002) reported that the concepts of customer satisfaction, commitment, confidence benefits significantly benefit the outcomes of services organisation in relationship marketing. Similarly, Basuki et al. (2019) examined relational benefits through several indicators, including confidence benefits that significantly influenced customer satisfaction and commitment. This study confirmed that confidence benefits are among the most effective ways of building customer satisfaction and keeping them.

The study's results also confirmed hypotheses seven and eight, which examined whether special treatment benefits are positively associated with customer satisfaction and commitment. These findings are in agreement with various empirical studies (Fatima et al., 2020; Chou and Chen, 2018; Fatima et al., 2018). Similarly, Gwinner et al. (1998) found a significant positive relationship between perceptions of commitment and satisfaction and special treatment benefits. Although these results are consistent with Hennig-Thurau et al. (2002), they reported that special treatment benefits play a little importance towards satisfaction, which is in line with Yang et al. (2017) that found an insignificant relationship between special treatment benefits and commitment. Therefore, to increase customers satisfaction and commitment, internet service providers must reward loyal customers with price breaks, special deals, and more individualised services than customers with lower levels of loyalty.

The results revealed that brand credibility is the most influential factor leading to customer satisfaction and commitment concerning hypotheses eight and nine. These findings are in agreement with various empirical studies (Jamshidi and Rousta, 2021; Dwivedi et al., 2019; Melewar et al., 2017; Othman et al., 2017). Similarly, Sweeney and Swait (2008) reported that high credibility leads to higher commitment than brands with lower credibility. Also, Ghorban and Tahernejad (2012) found that brand credibility had a significant positive relationship with customer satisfaction and loyalty in internet service providers. This is an essential finding for internet service providers and other service sectors. Because of service intangibility, it is harder for customers to evaluate service and distinguish it from competitors; thus, customers are less likely to switch brands or try new ones. All service communications should promise only what is possible and not attempt to make services more attractive than they are (Zeithaml et al., 2018). Therefore, it is important to consider the concept of credibility as one of the factors that can lead to customer satisfaction and commitment (Melewar et al., 2017). 
Finally, the empirical evidence indicated that customer satisfaction and commitment had a significant and positive impact on customer lifetime value (CLV), with customer satisfaction appearing as the strongest predictor than commitment. These findings are harmonious with various empirical studies (Raza et al.,2020; Joudeh and Dandis, 2018, Kasiri et al. 2016; Homburg et al., 2005). However, our results are not consistent with Chandrashekaran et al. (2007) cited by Qi et al. (2012) which reported that satisfaction does not guarantee future purchases. Similar results within mobile data service, or the internet services through mobile, where satisfaction was not a driver of CLV in the US and China (Qi et al., 2012). Like satisfaction, CLV can be positively impacted by loyalty and in some other cases, it cannot (Qi et al., 2012).

\section{Theoretical implications}

The proposed research model contributes to CRM theory by identifying CRM's constructs that can reflect its practice in actionable and practical organisational activities conducive to facilitating customer benefits and the firm's performance. This study included unique constructs that have typically not been seen together in previous studies. It attempts to simultaneously introduce technical quality, functional quality, brand credibility, special treatment benefits, confidence benefits on commitment and customer satisfaction, and CLV. This research also aims to fill the theoretical gap in marketing literature in general, particularly in the Middle East in large and Jordan as a specific population. This is the first study conducted in the Middle East as per the authors' knowledge. From an international marketing perspective, the current study's findings can be of significant value to other internet service providers. We hope that future research into this field will compare their findings with the results of the current study.

\section{Managerial implications}

This study offers various managerial implications for internet service providers to practise their customer relationship management. First, managers have to recognise the vital role of customer relationship management in creating greater value to increase their customer's satisfaction and commitment, which in turn increases customer lifetime value. Second, this study proves the crucial role of brand credibility in customers' perceived quality, leading to improved satisfaction and commitment. Therefore, management should ensure consistency in its marketing mix decisions; service decisions, prices, promotional activities and distribution channels. Furthermore, businesses should provide clarity of the brand message through their marketing communication activities to assure that their credibility can generate a positive perception from their customers (Morhart et al., 2015). 
Third, customer relationship management is greatly influenced by confidence benefits. Hence, businesses should inspire current customers' confidence because of its pivotal role in establishing customer commitment and satisfaction. Internet service providers need to keep on investing in monitoring and measuring the current customer's satisfaction and expectations. They should carry out various measures to provide confidence benefits to their customers, like Fatima, Mascio, and Johns (2018) found that it could lead to a higher level of competence trust from customers. Fourth, management should reward loyal customers by offering them special treatment, such as price breaks, tailored deals for their needs, and better and more customised services. This is proven through this research to increase their commitment and satisfaction to the organisation.

Fifth, despite the insignificance of the relationship between service quality and its two fundamental components; (functional and technical quality), and customer satisfaction, we argue this is because of the similarity of the service quality between competitors. Therefore, businesses should create a differentiating strategy for their services. Even with the implementation of technology such as artificial intelligence to help with CRM, Libai et al. (2020) suggested that businesses still need to focus on the core functions of CRM in building positive relationships with customers. The positive relationship between service quality and commitment strongly suggests that businesses should give special consideration to how their employees interact with the customers and how they deal with their requests and problems, providing continuous training to increase service quality because it is what customers use to measure service quality overall and the quality of the internet in specific.

Finally, with the current pandemic and increased competition in the market, businesses should focus on keeping the existing customers and increasing their lifetime value. Indeed, this research's finding makes the value of customer satisfaction and commitment, primarily to enhance customer lifetime value, as Crittenden (2020) suggested. These findings suggest that service quality, confidence benefits, special treatment and brand credibility are significant factors to be considered by management in their planning process to satisfy customer needs, creating more commitment and increasing their overall lifetime value.

\section{Limitations and future research}

Despite key contributions to the relationship marketing literature and the managerial implications, this research encompasses some limitations that should be examined. First, the research findings are based on the single service industry, the internet service providers, therefore, it would be beneficial to test the model with other service providers such as hotels and banks, or even other industries. Second, Because this research is cross-sectional that explored the correlations simultaneously, a future longitudinal study that looks into the developments and changes in the 
customers' lifetime value will enable a more accurate understanding of the cause and effect over time. Third, this research restricted the model to the examined constructs and their impact on customer lifetime value. However, the framework proposed by this research opens up future research avenues to look at how relational benefits and service quality can affect customer satisfaction and CLV in other countries and types of businesses, to increase the generalizability of the outcomes. Future replication and testing for different cross-cultural settings will be good to advance the recognising of diverse cultural features affecting CLV. Using the same independent variables, future research can also examine how relational benefits and service quality affect other variables such as trust and customer engagement. Lastly, the literature discussion and findings are useful for eCommerce CRM and managers will most probably benefit from the items of the variables. The measurement scales are a potentially useful and good source for further adaptations.

\section{References}

Aaker, D.A., Kumar, V., Leone, R.P. and Day, G.S. (2013), Marketing research, Eleventh, International student version. Wiley, Singapore.

AboElHamd, E., Abdel-Basset, M., Shamma, H.M., Saleh, M. and El-Khodary, I., (2021), "Modeling Customer Lifetime Value Under Uncertain Environment", Neutrosophic Sets and Systems, Vol. 39. No. 1, pp.10-30.

About Jordan - Minister of Digital Economy and Entrepreneurship. (2020). Retrieved 25 October 2020, from https://modee.gov.jo/EN/Pages/About_Jordan.

Akroush, M.N. and Mahadin, B.K. (2019), "An intervariable approach to customer satisfaction and loyalty in the internet service market", Internet research, Vol. 29, No. 4, pp. 772-798.

Ali, F., Hussain, K., Konar, R. and Jeon, H. (2017), "The Effect of Technical and Functional Quality on Guests' Perceived Hotel Service Quality and Satisfaction: A SEM-PLS Analysis", Journal of quality assurance in hospitality and tourism, Vol. 18, No. 3, pp. 354-378.

An, J., Do, D.K.X., Ngo, L.V. and Quan, T.H.M. (2019), "Turning brand credibility into positive word-of-mouth: integrating the signaling and social identity perspectives", The journal of brand management, Vol. 26, No. 2, pp. 157-175.

Arcand, M., PromTep, S., Brun, I. \& Rajaobelina, L. (2017), "Mobile banking service quality and customer relationships", International journal of bank marketing, Vol. 35, No. 7, pp. 1068-1089.

Aurier, P. and N'Goala, G. (2010),"The differing and mediating roles of trust and relationship commitment in service relationship maintenance and development", Journal of the Academy of Marketing Science, Vol. 38, No. 3, pp. 303-325. 
Badsi, H. B. A., Ghomari, A. R., and Zemmouchi-Ghomari, L. (2017), “A CRM process model for agent-based simulation”. International Journal of Service Science, Management, Engineering, and Technology (IJSSMET), Vol. 8, No 4, pp.56-82.

Basuki, R. A., Yulianto, E., and Pangestuti, E. (2019) “An Analysis on the Infleunce of Relational Benefits on Satisfaction, Commitment and Loyalty", Jurnal Sosial dan Humaniora, Vol. 22, No. 3, pp. 141-148.

Birkinshaw J, Morrison A and Hulland J (1995) Structural and competitive determinants of a global integration strategy. Strategic Management Journal 16(8): 637-655.

Bougoure, U.S., Russell-Bennett, R., Fazal-E-Hasan, S. and Mortimer, G. (2016), "The impact of service failure on brand credibility", Journal of retailing and consumer services, Vol. 31, pp. 6271.

Bowden-Everson, J.L., Dagger, T.S. and Elliott, G. (2013), "Engaging Customers for Loyalty in the Restaurant Industry: The Role of Satisfaction, Trust, and Delight", Journal of foodservice business research, Vol. 16, No. 1, pp. 52-75.

Buttle, F., and Maklan, S. (2019). Customer relationship management: concepts and techNologies. Routledge.

Chandrashekaran, M., Rotte, K., Tax, S.S. and Grewal, R. (2007), "Satisfaction Strength and Customer Loyalty", Journal of marketing research, Vol. 44, No. 1, pp. 153-163.

Chen, C. (2012), Conceptualising Customer Relationship Management and Its Impact on Customer Lifetime Value in the Taiwanese Banking Sector, De Montfort University.

Chou, S. and Chen, C. (2018), "The influences of relational benefits on repurchase intention in service contexts: the roles of gratitude, trust and commitment", The Journal of business \& industrial marketing, Vol. 33, No. 5, pp. 680-692.

Cohan, W. (2012), "Bloomberg - Are you a robot?". Retrieved 25 October 2020, from https://www.bloomberg.com/opinion/articles/2012-02-06/cohan-jordan-vc-firms-forgingmideast-silicon-valley.

Crittenden, V. (2020), "Customer support services: more than administrative support - it has to be strategic", European journal of marketing, Vol. 54, No. 7, pp. 1807-1808.

Cuong, D. T. (2020). The Impact of Brand Credibility and Perceived Value on Customer Satisfaction and Purchase Intention at Fashion Market. Journal of Advanced Research in Dynamical and Control Systems, Vol. 12, pp.691-700.

Curtis, T., Abratt, R., Rhoades, D. and Dion, P. (2011),"customer loyalty, repurchase and satisfaction: A meta-analytical review ", Journal of Consumer Satisfaction, Dissatisfaction and Complaining Behavior, Vol. 24, pp. 1-24.

Dagger, T.S. and O'Brien, T.K. (2010), "Does experience matter?: Differences in relationship benefits, satisfaction, trust, commitment and loyalty for novice and experienced service users", European journal of marketing, Vol. 44, No. 9/10, pp. 1528-1552. 
Dagger, T.S. and Sweeney, J.C. (2006), "The Effect of Service Evaluations on Behavioral Intentions and Quality of Life", Journal of service research : JSR, Vol. 9, No. 1, pp. 3-18.

Dahana, W.D., Miwa, Y. and Morisada, M. (2019), "Linking lifestyle to customer lifetime value: An exploratory study in an online fashion retail market", Journal of business research, vol. 99, pp. 319-331.

Dalla Pozza, I., Goetz, O., and Sahut, J. M. (2018). Implementation effects in the relationship between CRM and its performance. Journal of Business Research, Vol.89, pp.391-403.

Dandis, A.O. and Wright, L.T. (2020), "The effects of CARTER model on attitudinal loyalty in Islamic banks", International journal of quality and service sciences, Vol. 12, No. 2, pp. 149-171.

De Keyser, A. and Lariviere, B. (2014), "How technical and functional service quality drive consumer happiness: Moderating influences of channel usage", Journal of service management, Vol. 25, No. 1, pp. 30-48.

Dwivedi, A., Johnson, L.W., Wilkie, D.C. \& De Araujo-Gil, L. (2019), "Consumer emotional brand attachment with social media brands and social media brand equity", European journal of marketing, vol. 53, no. 6, pp. 1176-1204.

Erdem, T. and Swait, J. (2004), "Brand Credibility, Brand Consideration, and Choice", The Journal of consumer research, Vol. 31, No. 1, pp. 191-198.

Eskildsen, J., Kristensen, K., JØrn Juhl, H. and Østergaard, P. (2004), "The Drivers of Customer Satisfaction and Loyalty. The Case of Denmark 2000-2002", Total quality management and business excellence, Vol. 15, No. 5-6, pp. 859-868.

Expansion of Jordan's ICT sector remains a government priority. (2015), Retrieved 25 October 2020, from https://ox fordbusinessgroup.com/overview/dynamic-market-private-sector-ambitionsrising-internet-penetration-and-shift-4g-are-tran-0.

Famiyeh, S., Kwarteng, A. \& Asante-Darko, D. (2018), "Service quality, customer satisfaction and loyalty in automobile maintenance services: Evidence from a developing country", Journal of quality in maintenance engineering, Vol. 24, No. 3, pp. 262-279.

Farris, P. W., Bendle, N., Pfeifer, P. E., and Reibstein, D. (2010). Marketing metrics: The definitive guide to measuring marketing performance. Pearson Education.

Fatima, J.K. \& Mascio, R.D. (2020), "Synchronizing relational benefits with customer commitment profiles", Journal of strategic marketing, Vol. 28, No. 4, pp. 366-378.

Fatima, J.K., Mascio, R.D. \& Johns, R. (2018), "Impact of relational benefits on trust in the Asian context: Alternative model testing with satisfaction as a mediator and relationship age as a moderator", Psychology \& marketing, Vol. 35, No. 6, pp. 443-453.

Fatima, J.K., Razzaque, M.A. \& Di Mascio, R. (2016), "Modelling satisfaction-commitment relationship in developing country context", The International journal of quality \& reliability management, Vol. 33, no. 7, pp. 985-1001. 
Ghorban, Z. S., and Tahernejad, H. (2012), "A study on effect of brand credibility on word of mouth: With reference to internet service providers in Malaysia", International Journal of Marketing Studies, Vol. 4, No. 1, pp. 26.

Gong, T. and Yi, Y. (2018), "The effect of service quality on customer satisfaction, loyalty, and happiness in five Asian countries", Psychology and marketing, Vol. 35, No. 6, pp. 427-442.

Gremler, D.D., Van Vaerenbergh, Y., Bruggen, E.C. and Gwinner, K.P. (2020), "Understanding and managing customer relational benefits in services: a meta-analysis", Journal of the Academy of Marketing Science, Vol. 48, No. 3, pp. 565-583.

Gronroos, C. (1990). Service management and marketing. Lexington, MA: Lexington Books.

Grönroos, C. (1991), "Scandinavian Management and the Nordic School of ServicesContributions to Service Management and Quality", International journal of service industry management, Vol. 2, No. 3, pp. 17-26.

Gustafsson, A., Johnson, M.D. and Roos, I. (2005), "The Effects of Customer Satisfaction, Relationship Commitment Dimensions, and Triggers on Customer Retention", Journal of marketing, Vol. 69, No. 4, pp. 210-218.

Gwinner, K.P., Gremler, D.D. and Bitner, M.J. (1998), "Relational Benefits in Services Industries: The Customer's Perspective", Journal of the Academy of Marketing Science, Vol. 26, No. 2, pp. 101-114.

Hair, J.F., Ringle, C.M. \& Sarstedt, M. (2013), "Partial Least Squares Structural Equation Modeling: Rigorous Applications, Better Results and Higher Acceptance", Long range planning, Vol. 46, No. 1-2, pp. 1-12.

Hennig-Thurau, T., Gwinner, K.P. and Gremler, D.D. (2002), "Understanding Relationship Marketing Outcomes: An Integration of Relational Benefits and Relationship Quality", Journal of service research : JSR, Vol. 4, No. 3, pp. 230-247.

Ho, T., Park, Y. and Zhou, Y. (2006), "Incorporating Satisfaction into Customer Value Analysis: Optimal Investment in Lifetime Value", Marketing Science, Vol. 25, No. 3, pp. 260-277.

Homburg, C., Koschate, N. and Hoyer, W.D. (2005), "Do Satisfied Customers Really Pay More? A Study of the Relationship between Customer Satisfaction and Willingness to Pay", Journal of marketing, Vol. 69, No. 2, pp. 84-96.

Huang, P., Lee, B.C.Y. and Chen, C. (2019), "The influence of service quality on customer satisfaction and loyalty in B2B technology service industry", Total quality management \& business excellence, Vol. 30, No. 13-14, pp. 1449-1465.

Hulland, J. (1999), "Use of Partial Least Squares (PLS) in Strategic Management Research: A Review of Four Recent Studies", Strategic management journal, Vol. 20, No. 2, pp. 195-204.

Hussein, L.A., Baharudin, A.S. (2017), "Factors affecting small and medium enterprises (SMEs) continuance intention to adopt e-commerce in Jordan", International journal of advanced and applied sciences, vol. 4, no. 4, pp. 110-117. 
Jamshidi, D., and Rousta, A. (2021), "Brand Commitment Role in the Relationship between Brand Loyalty and Brand Satisfaction: Phone Industry in Malaysia", Journal of promotion management, Vol. 27, No. 1, pp. 151-176.

Joudeh, J. (2017), “The impact of service quality dimensions upon customers' satisfaction: an empirical study applied in the jordanian mobile telecommunication sector", International Review of Management and Business Research, Vol. 6 No. 1, p. 184.

Joudeh, J.M. and Dandis, A. (2018). Service quality, customer satisfaction and loyalty in an internet service providers. International Journal of Business and Management, Vol. 13, No. 8, pp.108-120.

Junior Ladeira, W., de Oliveira Santini, F. \& Carvalho Jardim, W. (2020), "The Influence of Brand Credibility on Consumers' Attention to Sales Promotions", Journal of promotion management, vol. 26, no. 6, pp. 855-873.

Kasiri, L.A., Guan Cheng, K.T., Sambasivan, M. and Sidin, S.M. (2017), "Integration of standardization and customization: Impact on service quality, customer satisfaction, and loyalty", Journal of retailing and consumer services, Vol. 35, pp. 91-97.

Keiningham, T.L., Frennea, C.M., Aksoy, L., Buoye, A. and Mittal, V. (2015), "A FiveComponent Customer Commitment Model: Implications for Repurchase Intentions in Goods and Services Industries", Journal of service research : JSR, vol. 18, no. 4, pp. 433-450.

Kotler, P., Keller, K. L., Brady, M., Goodman, M., and Hansen, T. (2019). Marketing management. Harlow, England: Pearson.

Krizanova, A., Gajanova, L. and Nadanyiova, M. (2018), "Design of a CRM Level and Performance Measurement Model", Sustainability, Vol. 10, No. 7, pp. 2567.

Kumar, V., and Reinartz, W. (2016). Creating enduring customer value. Journal of Marketing, Vol. 80, No.6, pp.36-68.

Lee, H. J., and Seong, M. H. (2020), "A Study on the Effects of Business Service Quality on Satisfaction, Commitment, Performance, and Loyalty at a Private University", The Journal of Asian finance, economics, and business, Vol. 7, No. 9, pp. 439-453.

Li, Y., Huang, J., and Song, T. (2019). Examining business value of customer relationship management systems: IT usage and two-stage model perspectives. Information \& Management, Vol.56, No.3, pp.392-402.

Libai, B., Bart, Y., Gensler, S., Hofacker, C.F., Kaplan, A., Kötterheinrich, K. and Kroll, E.B. (2020), "Brave New World? On AI and the Management of Customer Relationships", Journal of interactive marketing, vol. 51, pp. 44-56.

Malhotra, N.K., Nunan, D. and Birks, D.F. (2017), Marketing research: an applied approach, Pearson.

McCarthy, D.M., Fader, P.S. and Hardie, B.G.S. (2017), "Valuing Subscription-Based Businesses Using Publicly Disclosed Customer Data", Journal of marketing, vol. 81, no. 1, pp. 17-35. 
Meldrum, J. T., and Kaczynski, A. T. (2007), "Confidence, social and special treatment benefits as predictors of relationship strength in recreation settings", Leisure/Loisir: Ethnicity and Leisure, Vol. 31, No. 1, pp. 325-345.

Melewar, T.C., Foroudi, P., Gupta, S., Kitchen, P.J. and Foroudi, M.M. (2017), "Integrating identity, strategy and communications for trust, loyalty and commitment", European journal of marketing, Vol. 51, No. 3, pp. 572-604.

Middle East: Jordan — The World Factbook - Central Intelligence Agency, (2018). Retrieved 25 October 2020, from https://www.cia.gov/library/publications/the-worldfactbook/geos/jo.html\#field-anchor-communications-internet-users.

Min, S., Zhou, M., Kim, D. and Kim, J. (2013), "Assessing the e-Service Quality of Sellers in an Industrial e-Marketplace", Journal of promotion management, Vol. 19, No. 5, pp. 556-582.

Morhart, F., Malär, L., Guèvremont, A., Girardin, F. and Grohmann, B. (2015), "Brand authenticity: An integrative framework and measurement scale", Journal of consumer psychology, vol. 25, no. 2, pp. 200-218.

Neuman, W. L. (2014). Social research methods: Qualitative and quantitative approaches. Harlow, Essex: Pearson.

Ng, S., David, M.E. and Dagger, T.S. (2011), "Generating positive word-of-mouth in the service experience", Managing service quality, Vol. 21, No. 2, pp. 133-151.

Nicolas, C., Valenzuela-Fernández, L. and Merigó, J.M. (2020), "Research Trends of Marketing: A Bibliometric Study 1990-2017", Journal of promotion management, Vol. 26, No. 5, pp. 674-703.

Nikhashemi, S. R., Paim, L., Haque, A., Khatibi, A., and Tarofder, A. K. (2013), "Internet technology, Crm and customer loyalty: Customer retention and satisfaction perspective", Middle-East Journal of Scientific Research, Vol.14, No. 1, 79-92.

Oh, S.H., Lee, H.S. and Kim, S.J. (2011), "The Effects of Service Quality and Relationship Benefits on Relationship Commitment and Customer Loyalty in Membership Fitness Club", Journal of global scholars of marketing science, Vol. 21, No. 3, pp. 115-125.

Othman, M., Kamarohim, N., and Nizam, F. M. (2017), "Brand Credibility, Perceived Quality and Perceived Value: A Study of Customer Satisfaction”, International Journal of Economics and Management, , Vol. 11, No. 3, pp. 763-775.

Özkan, P., Süer, S., Keser, İ. K., and Kocakoç, İ. D. (2019), “The effect of service quality and customer satisfaction on customer loyalty”. International Journal of Bank Marketing, Vol. 38, No. 2, pp. 384-405.

Pallant, J. (2020), SPSS survival manual: a step by step guide to data analysis using IBM SPSS, 7th edn, McGraw Hill, London, England.

Parasuraman, A., Zeithaml, V.A. and Berry, L.L.6. (1988), "SERVQUAL: a multiple-item scale for measuring consumer perceptions of service quality", Journal of retailing, Vol. 64, No. 1, pp. 12. 
Park, J., Lee, J., Lee, H. and Truex, D. (2012), "Exploring the impact of communication effectiveness on service quality, trust and relationship commitment in IT services", International journal of information management, Vol. 32, No. 5, pp. 459-468.

Pritchard, M.P., Havitz, M.E. and Howard, D.R. (1999), "Analyzing the Commitment-Loyalty Link in Service Contexts", Journal of the Academy of Marketing Science, Vol. 27, No. 3, pp. 333348.

Qi, J., Zhou, Y., Chen, W. and Qu, Q. (2012), "Are customer satisfaction and customer loyalty drivers of customer lifetime value in mobile data services: a comparative cross-country study", Information technology and management, Vol. 13, No. 4, pp. 281-296.

Rather, R.A. (2018), "Investigating the Impact of Customer Brand Identification on Hospitality Brand Loyalty: A Social Identity Perspective", Journal of hospitality marketing and management, Vol. 27, No. 5, pp. 487-513.

Rather, R.A. and Sharma, J. (2017), "The Effects of Customer Satisfaction and Commitment on Customer Loyalty: Evidence from the Hotel Industry", JOHAR, Vol. 12, No. 2, pp. 41-60.

Rather, R.A., Tehseen, S., Itoo, M.H. \& Parrey, S.H. (2019), "Customer brand identification, affective commitment, customer satisfaction, and brand trust as antecedents of customer behavioral intention of loyalty: An empirical study in the hospitality sector", Journal of global scholars of marketing science, Vol. 29, No. 2, pp. 196-217.

Raza, S.A., Umer, A., Qureshi, M.A. \& Dahri, A.S. (2020), "Internet banking service quality, ecustomer satisfaction and loyalty: the modified e-SERVQUAL model", TQM journal, Vol. 32, No. 6, pp. 1443-1466.

Sallam, M.A. (2015). The effects of brand credibility on customers wom communication: the mediating role of brand commitment. European Journal of Business and Social Sciences, Vol 4, No.9, pp.164-176.

Santouridis, I. and Veraki, A. (2017), "Customer relationship management and customer satisfaction: the mediating role of relationship quality", Total quality management and business excellence, Vol. 28, No. 9-10, pp. 1122-1133.

Schmidt, M. J., and Hollensen, S. (2006). Marketing research: An international approach. Harlow: Financial Times Prentice Hall.

Segarra-Moliner, J.R. and Moliner-Tena, M.Á. (2016), "Customer equity and CLV in Spanish telecommunication services", Journal of business research, Vol. 69, No. 10, pp. 4694-4705.

Shams, R., Brown, M. \& Alpert, F. (2017), "The role of brand credibility in the relationship between brand innovativeness and purchase intention", Journal of customer behaviour, Vol. 16, No. 2, pp. 145-159.

Sharifi, S.S. and Esfidani, M.R. (2014), "The impacts of relationship marketing on cognitive dissonance, satisfaction, and loyalty: The mediating role of trust and cognitive dissonance", International journal of retail and distribution management, Vol. 42, No. 6, pp. 553575. 
Sohrabi, B. and Khanlari, A. (2007), "Customer Lifetime Value Measurement Based on RFM Model,” Iranian Accounting and Auditing Review, Vol. 14, No. 47, pp. 7-20.

Srivastava, A., Dey, D.K. \& M.S, B. (2020), "Drivers of brand credibility in consumer evaluation of global brands and domestic brands in an emerging market context", The Journal of Product and brand management, Vol. 29, No. 7, pp. 849-861.

Su, L., Swanson, S.R., Chinchanachokchai, S., Hsu, M.K. and Chen, X. (2016), "Reputation and intentions: The role of satisfaction, identification, and commitment", Journal of business research, Vol. 69, No. 9, pp. 3261-3269.

Sweeney, J. and Swait, J. (2008), "The effects of brand credibility on customer loyalty", Journal of retailing and consumer services, Vol. 15, No. 3, pp. 179-193.

Teeroovengadum, V., Nunkoo, R., Gronroos, C., Kamalanabhan, T.J. \& Seebaluck, A.K. (2019), "Higher education service quality, student satisfaction and loyalty: Validating the HESQUAL scale and testing an improved structural model", Quality assurance in education, Vol. 27, No. 4, pp. 427-445.

Thaichon, P. and Quach, T.N. (2015), "The relationship between service quality, satisfaction, trust, value, commitment and loyalty of Internet service providers' customers", Journal of global scholars of marketing science, Vol. 25, No. 4, pp. 295-313.

Wang, H., Kim, K.H., Ko, E. \& Liu, H. (2016), "Relationship between service quality and customer equity in traditional markets", Journal of business research, Vol. 69, No. 9, pp. $3827-$ 3834.

Wirtz, J. and C.H. Lovelock. (2018). Essentials of services marketing. Pearson

Wong, K.H., Chang, H.H. and Yeh, C.H. (2019), "The effects of consumption values and relational benefits on smartphone brand switching behavior", Information technology \& people, Vol. 32, No. 1, pp. 217-243.

Yang, S., Song, Y., Chen, S. \& Xia, X. 2017, "Why are customers loyal in sharing-economy services? A relational benefits perspective", The Journal of services marketing, Vol. 31, No. 1, pp. 48-62.

Yi, Y. \& Nataraajan, R. (2018), "Customer satisfaction in Asia", Psychology \& marketing, Vol. 35, No. 6, pp. 387-391.

Zeithaml, V. A., Bitner, M. J., and Gremler, D. D. (2018). Services marketing: Integrating customer focus across the firm. New York: McGraw-Hill Education.

Zeithaml, V.A., Berry, L.L. and Parasuraman, A. (1996), "The Behavioral Consequences of Service Quality", Journal of marketing, Vol. 60, No. 2, pp. 31-46.

Acknowledgment: The first author is grateful to the Applied Science Private University, Amman, Jordan for the financial support granted to this research project. 